\title{
Effect of Supplementation of Rumen-Protected Amino Acids to Barki Sheep on Some Blood
}

\section{Parameters}

\author{
Younis, F. E. and Reda, A. Abd-Elazem
}

Animal and Poultry Physiology Department, Animal and Poultry Production Division, Desert Research Center, Egypt.

\begin{abstract}
The objective of this study was to evaluate the effects of supplementing a traditional diet with rumenprotected (RP) either methionine (MET) or lysine (LYS) or their combination, on some physiological responses of ewes. Twenty-four adult Barki ewes were used were divided into four groups (6 ewes for each). The first group (Control) was fed only the control diet. The second group (LYS) fed the control diet and rumen-protected LYS (6g Lysi pearl $\mathrm{kg}$ concentrate i.e. $3 \mathrm{~g}$ /animal/day). The third group (MET) was fed the control diet and rumen-protected MET (14g Smartamin/ $\mathrm{kg}$ concentrate i.e. $7 \mathrm{~g}$ /animal/day). The fourth group (MIX) was fed the control diet and mixture of $3 g$ LYS and $7 g$ MET/animal/day. The experiment lasted for six months. Blood total proteins, urea, creatinine, total cholesterol, glucose, alanine aminotransferase, aspartate aminotransferase, alkaline phosphatase and lactate dehydrogenase were detected. Total lipids (TL), high-density lipoproteins (HDL), low-density lipoproteins (LDL), and some plasma essential and non-essential amino acids were also analyzed.

Supplemented ewes, especially with mixed LYS and MET, showed higher levels of TL, HDL, LDL, but lower creatinine. Treatment resulted in increased plasma Arginine, Lysine and Glutamine, while Leucine and Proline decreased. Other measured parameters were not affected.
\end{abstract}

Keywords - sheep, protected-Methionine and Lysine, blood biochemical parameters.

\section{INTRODUCTION}

Protein is an important nutrient in ruminants fed low-quality forages. It becomes very necessary when animal attains its optimum growth or peak production. Moreover, nutrient requirements of ruminants vary according to the physiological state like growth, lactation and pregnancy. It is well accepted that amino acids, as nutrients, are building blocks of protein and play an essential role in the nutritional composition of a feedstuff.

The ruminants derive their amino acids from dietary protein which escapes rumen degradation and microbial protein synthesized in the rumen. The amount of protein and amino acids that escapes rumen degradation varies greatly among different feeds, depending on their solubility and the rate of passage to the small intestine (Kaufman and Lupping, 1982). In some situations, animal's requirements for amino acids not fully met from the normal sources of dietary protein.

Rapid and extensive degradation of valuable proteins in the rumen lead research to develop the concept of protein protection from ruminal degradation with the principal objective of enhancing the supply of essential amino acids to the productive animal and reduction of nitrogen losses as urea in the urine (Annison, 1981). Ruminant animals fed on poor quality forages with inadequate protein showed better performance with supplementation of quality protein or rumen-protected amino acid (RPAA) particularly methionine and lysine.

The main objective of this research was to investigate the effect of supplementation with rumenprotected amino acids, methionine or/and lysine on some plasma biochemical that indicate protein, energy and fat metabolism in Barki sheep in addition to plasma content of some essential and non-essential amino acids.

\section{MATERIALS AND METHODS}

The present study was conducted at Maryout Research Station, belonging to Desert Research Center, Ministry of Agriculture and Land Reclamation (Latitude $31.02^{\circ} \mathrm{N}$, longitude $29.80^{\circ} \mathrm{E}$ ) located $35-\mathrm{km}$ south-west of Alexandria. The experiment was carried out from September 2016 to February 2017. 


\section{Animals and Management:}

Twenty-four adult dry Barki ewes were used in this study. Age of ewes ranged between 3 and 4 years and average live body weight was $28.95 \pm 1.37 \mathrm{~kg}$. The experimental animals were clinically examined to be healthy and free from diseases. They were fed on Berseem hay (Trifolium alexandrinum) that offered ad-libitum plus concentrate feed mixture (14\% $\mathrm{CP}$ and $60 \% \mathrm{TDN}$,$) at a rate$ of $1 / 2 \mathrm{~kg} / \mathrm{ewe} /$ day. Concentrate feed mixture was composed of $50 \%$ cottonseed cake, $18 \%$ wheat bran, $15 \%$ yellow corn, $11 \%$ rice polish, $3 \%$ molasses, $2 \%$ limestone and $1 \%$ common salt. Proximate analyses were determined by the standard AOAC (2005), while nitrogen-free extract (NFE) was determined by the calculated difference (Table 1). Drinking water was provided twice daily.

Table.1: Proximate chemical analysis of different experimental roughages and concentrate feed mixture, (CFM) on Dry matter basis.

\begin{tabular}{|l|c|c|}
\hline \multirow{2}{*}{ Items } & \multicolumn{2}{|c|}{ Experimental rations } \\
\cline { 2 - 3 } & Hay & CFM \\
\hline Dry Matter\% & $\mathbf{8 8 . 8 0}$ & $\mathbf{8 9 . 6 6}$ \\
\hline Crude Protein\% & 17.50 & 14.20 \\
\hline Crude Fiber\% & 28.20 & $\mathbf{8 . 1 4}$ \\
\hline Ether extract\% & 1.38 & 3.36 \\
\hline Nitrogen free extract\% & 41.30 & $\mathbf{6 9 . 7 4}$ \\
\hline Ash\% & 11.61 & 4.56 \\
\hline
\end{tabular}

\section{Experimental Design:}

The experimental ewes were divided according to their live body weight into four groups ( 6 ewes each). The first group (Control): fed only the control diet. The second group (LYS) fed the control diet and rumen-protected lysine (3 g Lysipearl/animal/day). The third group (MET) fed the control diet and rumen-protected methionine (7 $\mathrm{g}$ Smartamin/animal/day) individually. The fourth group (MIX) fed the control diet and mixture of $3 \mathrm{~g}$ LYS and $7 \mathrm{~g}$ MET/animal/day). The rumen-protected amino acids in this experiment were obtained from United Biomed Company, Egypt.

\section{Blood Biochemical Analyses:}

Blood samples were collected from the jugular vein of each animal at the end of the experiment. The samples were collected in tubes containing anticoagulant (EDTA) and centrifuged at $3000 \mathrm{rpm}$ for $30 \mathrm{~min}$. Plasma was determined and stored at $-18{ }^{\circ} \mathrm{C}$ until laboratory assays. Biochemical analyses included some energy and protein metabolism indicators which were total protein (TP), glucose (Glu) and lactate dehydrogenase (LDH) activities. For lipid profile, cholesterol (Chol), total lipids (TL), high-density lipoproteins (HDL), and low-density lipoproteins (LDL) were assayed. For liver and kidney function plasma alanine aminotransferase (ALT), aspartate aminotransferase (AST), alkaline phosphatase (ALP), urea and creatinine were examined. The analysis was conducted by standard methods using commercial kits supplied from Rosche Diagnostics (D68298, Mannheim, Germany) in Roche Cobas C111 Clinical Chemistry Analyzer.

\section{Amino acids Analysis:}

Evaluation of plasma amino acids was executed using amino acid analyzer (Sykam Clarity Amino Acid Analyzer SW, Central Lab of Desert Research Center) according to (Pellet and Young, 1980).

\section{Statistical Analysis:}

Statistical analysis was carried out using A General Linear Model (GLM) procedures by SAS (2008) was used for statistical one-way analysis of variance. Duncan's New Multiple Range Test (Duncan, 1955) was used for separated differences among treatment means.

The linear model was: $\mathbf{Y}_{\mathbf{i j}}=\boldsymbol{\mu}+\mathbf{G}_{\mathbf{i}}+\mathbf{e}_{\mathbf{i j}}$

Where: $\mathrm{Y}_{\mathrm{ij}}=$ Dependent variable.

$\mu=$ is the overall mean.

$\mathrm{Gi}=$ is the group effect $\mathrm{i}^{\text {th }}(\mathrm{i}=1,2,3,4$ where $1=$ control group, $2=$ lysine group, $3=$ methionine group and $4=$ lysine and methionine mixture group).

$\mathrm{e}_{\mathrm{ij}}=$ The random errors assumed to be normally distributed with mean $=0$ and variance $={ }^{2}$. 


\section{RESULTS AND DISCUSSIONS}

The effects on metabolic plasma indicators:

The effect of supplementation with protected amino acids on plasma biochemical parameters of Barki ewes that indicate metabolic statues are presented in Table (2). No significant differences were observed among treatments concerning the plasma contents of TP, Glu and Chol. Moreover, they were within the normal range as stated by Peter et al.. (2002). On the other hand, TL increased $(\mathrm{P}<0.05)$ by treatments. Adding LYS or MIX could keep the level of HDL, but decreased LDL. However, adding MET decreased $(\mathrm{P}<0.05)$ HDL, the same trends reported by Hosseintabar et al., (2015) and Ma et al., (2014).

The glucose (Glu) and free fatty acids concentrations are good indicators of the energetic status. The dynamic interactions between these two major energy substrate pools, without hormonal mediation seems to indicate that the utilization of one nutrient (e.g. glucose) directly inhibits the use of the other (in this case fatty acids) in accordance with Hosseintabar et al., (2015) and Arslan et al., (2014).
Bouyeh and Gevorgyan (2011) observed a decrease followed by an increase in plasma cholesterol in birds feed Lys and Met above NRC recommendations.

These differences might be explained as the ability to completely oxidize non-esterified fatty acids (NEFA) and synthesize very-low-density lipoprotein (VLDL) is limited, thereby increasing the incidence rates of ketosis and fatty liver (Grummer et al.., 2004). Choline and methionine help in the transport of hepatic lipids by promoting the synthesis of phosphatidylcholine to package VLDL. Specifically, both of them play vital roles in 1-carbon unit transfer of dairy cows, modulate the synthesis of S-adenosylmethionine (SAM) in methionine cycle, and SAM functions as the most important methyl donor in the phosphatidylethanolamine to phosphatidylcholine formation (Osorio et al., 2014). Supply of methionine and choline enhance the capacity of liver to export triacylglycerol in the form of VLDL and help ameliorate the negative effects of fatty acid accumulation in the liver.

Table.2: Effect of adding lysine and methionine on some blood biochemical parameters of Barki ewes

\begin{tabular}{|c|c|c|c|c|c|}
\hline \multirow{2}{*}{ Parameter } & \multicolumn{4}{|c|}{ Treatment } & \multirow{2}{*}{$\begin{array}{c}\text { Treatmen } \\
\text { SE }\end{array}$} \\
\hline & CON & LYS & MET & MIX & \\
\hline Total Protein, g/dl & 6.08 & 6.74 & 6.70 & 6.77 & 0.25 \\
\hline Glucose, mg/dl & 68.75 & 70.58 & 70.70 & 70.50 & 2.30 \\
\hline Cholesterol, mg/dl & 84.10 & 87.33 & 85.64 & 91.33 & 3.41 \\
\hline Total Lipids, mg/dl & $731.41^{b}$ & $895.16^{a}$ & $\mathbf{8 5 7 . 9 8}^{\mathrm{a}}$ & $878.45^{\mathrm{a}}$ & 39.78* \\
\hline HDL, mmol/l & $38.37^{a b}$ & $39.51^{\mathrm{a}}$ & $\mathbf{3 5 . 7 8}^{\mathrm{b}}$ & $40.53^{a}$ & $1.02 *$ \\
\hline LDL, mmol/l & $\mathbf{3 2 . 5 8}^{\mathrm{b}}$ & $27.73^{b}$ & $36.82^{b}$ & $50.40^{a}$ & $4.56^{*}$ \\
\hline
\end{tabular}

CON, Control group; LYS, Lysine group; MET, Methionine group and MIX, Lysine and Methionine mixture; HDL, high-density

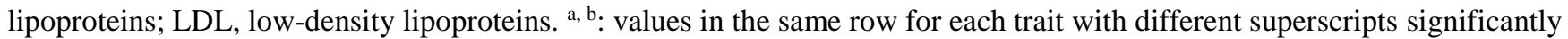
differ at $\mathrm{P}<0.05$.

\section{The effect on kidney and liver functions:}

The effect of adding protected amino acids on the plasma compounds indicating kidney and liver functions of Barki ewes is presented in table (3). No significant differences were observed between treatments concerning the entire blood indicators of kidney and liver functions (urea, ALT, AST and ALP). Moreover, they were within the normal average as described by Peter et al. (2002). On the other hand, creatinine decreased $(\mathrm{P}<0.05)$ by adding rumenprotected LYS or MET and to a lesser extent by adding a mixture of both amino acids.
These results might point to that supplementation of both LYS and MET significantly decreased urea N concentration in plasma. Von Keyserlingk et al. (1999) observed that multiparous cows receiving a diet supplemented with bypass methionine and bypass protein had significantly lower blood urea nitrogen and creatinine levels when compared with the control ones. They added that cows receiving the bypass methionine and bypass protein with lower crude protein diets were able to maintain milk production. Moreover, Hellwing et al. (2007) explained that the plasma concentration of creatinine tended to decline with increasing protein meal levels. 
Table.3: Effect of adding lysine and methionine on some Kidney and Liver functions of Barki ewes

\begin{tabular}{|l|c|c|c|c|c|}
\hline \multirow{2}{*}{ Items } & \multicolumn{4}{|c|}{ Treatments } & \multirow{2}{*}{ \pm SE } \\
\cline { 2 - 5 } & CON & LYS & MET & MIX & \\
\hline Urea, mg/dl & 32.25 & 33.02 & 31.26 & 28.47 & 1.81 \\
\hline Creatinine, mg/dl & $1.10^{\text {a }}$ & $\mathbf{0 . 7 6}^{\text {b }}$ & $\mathbf{0 . 7 3}^{\mathbf{b}}$ & $\mathbf{0 . 9 5}^{\text {bb }}$ & $\mathbf{0 . 0 7}^{*}$ \\
\hline ALT, U/L & 24.80 & 22.94 & 24.40 & 25.51 & 1.11 \\
\hline AST, U/L & 33.51 & 34.84 & 36.06 & 33.40 & 2.21 \\
\hline Alkaline Phosphates, g/dl & 35.85 & 41.99 & 41.51 & 36.01 & 3.96 \\
\hline
\end{tabular}

CON, Control group; LYS, Lysine group; MET, Methionine group; and MIX, Lysine and Methionine mixture; NS, non-significant. * Significant at $\mathrm{P}<0.05$, a, b: Values in the same row for each trait with different superscripts significantly differ at $\mathrm{P}<0.05$.

Changes in plasma content of amino acids:

The effect of adding protected amino acids on plasma content of essential (EAA) and non-essential amino acid (NEAA) of Barki ewes are presented in Table (4).
Adding protected LYS or/and MET caused a significant increase in plasma levels of arginine, lysine and glutamine, while it caused significant decrease in proline and to some extent leucine.

Table.4: Effect of addition protected amino acids on plasma content of essential amino acid and Non-essential amino acid (\%) in Barki ewes

\begin{tabular}{|c|c|c|c|c|}
\hline \multirow{2}{*}{ Amino acid } & \multicolumn{4}{|c|}{ Treatments } \\
\hline & CON & Lysine & Methionine & MIX \\
\hline \multicolumn{5}{|c|}{ Essential amino acids } \\
\hline Arginine & $2.79 \pm 0.05^{b}$ & $4.00 \pm 0.32^{\mathrm{a}}$ & $4.20 \pm 0.24^{a}$ & $4.10 \pm 0.24^{a}$ \\
\hline Histidine & $3.61 \pm 0.07$ & $3.30 \pm 0.21$ & $3.92 \pm 0.23$ & $3.60 \pm 0.21$ \\
\hline Isoleucine & $3.07 \pm 0.06$ & $3.00 \pm 0.17$ & $2.96 \pm 0.17$ & $3.10 \pm 0.18$ \\
\hline Leucine & $9.43 \pm 0.16^{a}$ & $8.20 \pm 0.47^{b}$ & $8.46 \pm 0.49^{a b}$ & $8.60 \pm 0.50^{\mathrm{ab}}$ \\
\hline Lysine & $8.83 \pm 0.16^{b}$ & $10.60 \pm 0.61^{\mathrm{a}}$ & $10.20 \pm 0.59^{a}$ & $10.40 \pm 0.60^{\mathrm{a}}$ \\
\hline Phenylalanine & $5.30 \pm 0.09$ & $5.10 \pm 0.29$ & $5.50 \pm 0.32$ & $5.40 \pm 0.31$ \\
\hline Threonine & $5.81 \pm 0.14$ & $6.60 \pm 0.38$ & $6.58 \pm 0.38$ & $6.60 \pm 0.38$ \\
\hline Valine & $7.07 \pm 0.08$ & $7.40 \pm 0.43$ & $7.90 \pm 0.46$ & $7.10 \pm 0.41$ \\
\hline Methionine & $0.26 \pm 0.16$ & $0.4 \pm 0.02$ & $0.32 \pm 0.02$ & $0.33 \pm 0.02$ \\
\hline \multicolumn{5}{|c|}{$\underline{\text { Non-essential amino acids }}$} \\
\hline Tyrosine & $4.43 \pm 0.11$ & $4.80 \pm 0.28$ & $4.60 \pm 0.27$ & $4.70 \pm 0.27$ \\
\hline Cysteine & $2.30 \pm 0.10$ & $2.20 \pm 0.13$ & $2.40 \pm 0.14$ & $2.30 \pm 0.13$ \\
\hline Glutamine & $12.49 \pm 0.12^{b}$ & $14.80 \pm 0.85^{\mathrm{a}}$ & $14.50 \pm 0.84^{a}$ & $14.62 \pm 0.84^{a}$ \\
\hline Glycine & $5.53 \pm 0.16$ & $4.10 \pm 0.24$ & $3.90 \pm 0.23$ & $2.12 \pm 0.24$ \\
\hline Proline & $6.06 \pm 0.06^{\mathrm{a}}$ & $3.70 \pm 0.21^{b}$ & $3.40 \pm 0.20^{b}$ & $3.84 \pm 0.22^{b}$ \\
\hline Serine & $5.38 \pm 0.12$ & $5.40 \pm 0.31$ & $5.30 \pm 0.31$ & $5.20 \pm 0.30$ \\
\hline Alanine & $4.94 \pm 0.05$ & $5.20 \pm 0.30$ & $4.90 \pm 0.28$ & $5.10 \pm 0.29$ \\
\hline Asparagine & $8.23 \pm 0.35$ & $9.50 \pm 0.55$ & $9.61 \pm 0.55$ & $9.60 \pm 0.55$ \\
\hline
\end{tabular}

Mean values with different superscripts within the same row are significantly different at $(\mathrm{P}<0.05)$

Han et al. (1996) stated that supplementing rumenprotected lysine in the diets of sheep caused an increase in plasma concentrations of lysine, arginine, asparagine, threonine, serine, valine and leucine compared with control 
ones. Oke et al. (1986) found that feeding rumen-protected lysine or rumen-protected methionine and abomasal infusion of lysine caused similar increase in plasma concentration of these amino acids, but feeding unprotected lysine and methionine did not increase plasma levels of these amino acids. Other researchers have demonstrated that blood concentration of limiting amino acids remains relatively constant until tissue requirements are met (Nimrick et al., 1970 and Bergen, 1979). Also, when sheep were infused of $1.06 \mathrm{~g}$ methionine, in 2 equal doses daily, there was an increase in molar proportions of lysine and methionine in plasma and there decreases in plasma threonine (Amos et al., 1974). However, Reis et al. (1973) confirmed that supplementation of dietary methionine (ten grams per day) didn't cause any change in the total content of plasma amino acids nor in the concentration of any individual amino acid.

\section{CONCLUSION}

Adding protected amino acids lysine or/and methionine did not affect plasma TP or glucose, while caused a significant increase in some blood AA without any adverse effect on kidney and liver functions. Rumen protected amino acids must be provided in a ruminant diet as they will be available in the small intestine for complete absorption. Among rumen-protected amino acids, Lys and Met are so important since their deficiency limited the milk production and growth of ruminant animals. Supplementation of these amino acids was especially useful in rations with, particularly low protein content.

\section{REFERENCES}

[1] A.O.A.C. (2005) Official methods of analysis association of Analytical chemists, 16th ed. Aoac. International, Washington, DC., USA.

[2] Amos, H.E., Little, C.O., Digenis, G.A., Schelling, G.T., Tucker, R.E. and Mitchell, G.E. Jr. (1974). Methionine, DLhomocysteine thiolactone and n-acetyl-DLmethionine for ruminants. J. Anim Sci., 39 (3): 612-617.

[3] Annison, E.F. (1981). The role of protein which escapes ruminal degradation. (Recent Advances in Animal Nutrition in Australia, Armidale, Australia, University of New England Publishing Unit: Ed. Farrell, D.J.) 40-41.

[4] Arslan, C., Citil, M., and Saatci, M. (2004). Effect of LCarnitine administration on growth performance, carcass traits, serum lipids and abdominal fatty acid compositions of geese. Revue de médecine vétérinaire, 155, 315-320.

[5] Bergen, W. G. (1979). Free amino acids in blood of ruminants-physiological and nutritional regulation. J. Anim. Sci., 49:1577.
[6] Bouyeh, M., and Gevorgyan, O. (2011). Influence of excess lysine and methionine on cholesterol fat and performance of broiler chicks. J Anim Vet Adv, 10(12), 1546-1550.

[7] Duncan, D.B. (1955). Multiple Range and Multiple F Test. Biometric, 11:1-42.

[8] Grummer, R. R., Mashek, D. G., and Hayirli, A. (2004). Dry matter intake and energy balance in the transition period. Veterinary Clinics: Food Animal Practice, 20 (3), 447470.

[9] Han, I.K., Ha, J., Lee, S., Ko, Y. and Lee, H. (1996). Effect of supplementing rumenprotected lysine on growth performance and plasma amino acid concentrations in sheep. Australasian Journal of Animal Sciences, 9 (3): 309-313.

[10] Hellwing, A.L.F., Tauson, A. H. and Skrede, A. (2007). Blood parameters in growing pigs fed increasing levels of bacterial protein meal. Acta Veterinaria Scandinavica, 49: 33.

[11] Hosseintabar, B., Dadashbeiki, M., Bouyeh, M., Seidavi, A., van den Hoven, R., and Gamboa, S. (2015). Effect of different levels of L-carnitine and lysine-methionine on broiler blood parameters. Revista MVZ Córdoba, 20(3), 4698-4708.

[12] Ma, L. L., Ji, G. Y., and Jiang, Z. Q. (2014). Influence of dietary amino acid profile on serum lipids in hypercholesterolemic Chinese adults. J Nutr Food Sci, 4(258), 2.

[13] Nimrick, K., Hatfield, E.E., Kaminski, J. and Owens, F.N. (1970). Qualitative assessment of supplemental amino acid needs for growing lambs fed urea as the sole nitrogen source. J. Nutr., 100:1293-1300.

[14] Oke, B., Loerch, S. and Deetz, L. (1986). Effects of rumenprotected methionine and lysine on ruminant performance and nutrient metabolism. Journal of animal science, 62 (4):11011112.

[15] Osorio, J. S., Ji, P., Drackley, J. K., Luchini, D. and Loor, J. J. (2014). Smartamine $\mathrm{M}$ and MetaSmart supplementation during the peripartal period alter hepatic expression of gene networks in 1-carbon metabolism, inflammation, oxidative stress, and the growth hormone-insulin like growth factor 1 axis pathways. J. Dairy Sci, 97(12), 7451-7464.

[16] Pellet, P. L. and Young,V. R. (1980). Nutritional evaluation of protein foods . published by the United Nation University.

[17] Reis, P. J., Tunks, D. and Downes, A. (1973). The influence of abomasal and intravenous supplements of sulfur-containing amino acids on wool growth rate. Australian Journal of biological sciences, 26 (1): 249-258.

[18] SAS (2008). User's Guide. Statistics. Version 9.2 edition. SAS Institute Inc., Cary, NC.

[19] Von Keyserlingk, M. A. G., Swift, M. L. and Shelford, J. A. (1999). Use of the Cornell Net Carbohydrate and Protein System and rumen-protected methionine to maintain milk production in cows receiving reduced protein diets. Can. J. Anim. Sci. 79: 397-400. 